\title{
BINA-DAMAI DALAM KOMUNITAS PESANTREN: Sebuah Upaya Counter-Radikalisme
}

\author{
Rahman Mantu \\ Universitas Islam Negeri (UIN) Sunan Kalijaga Yogyakarta \\ e-mail: muhammadrahman530@ymail.com
}

\begin{abstract}
This article discussed about the experience of al-Qodir Boarding School in Sleman Yogyakarta in the effort to counter the radicalism through the approach of peace building. Applying qualitative approach, this research using the methods of observation and deep interview in collecting data. With the theoritical framework of cognitive peace building, three factors of peace building became the focus; the mechanism of internal group, among group and external group. The main research finding here was the essential role of kiai in building participative dialogue with the community out of the boarding school which was implemented through social actions. It resulted in the ability of al-Qodir Boarding School in formulating the strategy of radicalism counter which became a typical strategy of pesantren among so many strategies to find out new formulations in avoiding the movement of radicalism in Indonesia.

Tulisan ini akan membahas tentang pengalaman Pondok Pesantren Al-Qodir terhadap upaya counter-radikalisme melalui pendekatan bina-damai di Sleman Yogyakarta. Penelitian ini menggunakan metode kualitatif dengan melakukan pengamatan serta wawancara mendalam. Kerangka teoritik yang digunakan peneliti adalah teori peace building. Perdamaian menurut teori ini bisa tercipta karena tiga faktor; mekanisme internal, antar kelompok dan eksternal. Temuan dari riset ini adalah adanya peran penting kiai dalam membangun dialog partisipatif dengan masyarakat luar pesantren yang terimplementasi melalui aksi-aksi sosial. Hasilnya Pesantren Al-Qadir mampu merumuskan strategi counter-radikalisme yang khas pesantren ditengah upaya banyak pihak mencari formulasi baru dalam menangkal gerakan radikalisme di Indonesia.
\end{abstract}

Keywords: Pesantren Al-Qodir, bina-damai, plural, counter-radikalisme 


\section{A. Pendahuluan}

Pesantren kini telah menjadi isu global. diperbincangkan di berbagai forum dunia, dianalisa oleh berbagai peneliti juga dijadikan salah satu objek kebijakan yang penting dari negara-negara barat. Namun demikian patut disayangkan bahwa naiknya pamor pesantren ke panggung dunia tersebut lebih dipengaruhi oleh faktor-faktor yang sejatinya bertentangan dengan ide dasar pesantren itu sendiri, yaitu kekerasan atau intoleransi. Seperti kita ketahui banyak peristiwa kekerasan, terutama yang terjadi dalam tragedi Bom Bali misalnya, telah menjadikan pesantren sebagai "kambing hitam" sehingga muncul klaim "pesantren adalah sarang teroris". Padahal, keterlibatan oknum pesantren maupun umat Islam dalam bom bali maupun bom-bom lain di tanah air adalah peristiwa yang paling banyak melukai kalangan pesantren maupun umat Islam itu sendiri. Tokoh-tokoh Islam justru tampil paling depan untuk meminta supaya siapa pun yang melakukan kejahatan kemanusiaan itu, apakah dia Islam, Kristen, Hindu, Buddha, atau Konghucu, harus dihukum seberatberatnya, tanpa pandang bulu. Karena perbuatan mereka itu, apapun alasan dan motivasinya, jelas bertentangan dengan nilai-nilai moral agama manapun di muka bumi ini.

Pesantren yang secara keliru dilaporkan sebagai "dunia tertutup”, justru memproduksi kader-kadernya dalam jumlah besar yang akhirnya tampil sebagai pengusung ide-ide "keterbukaan" di tanah air. Para alumni pesantren justru hadir sebagai kaum pluralis. tapi, sepak terjang mereka dicurigai oleh kalangan Islam fundamentalis sebagai kaum yang "terbaratkan". Posisi itu, sampai batas tertentu, masih juga terasa gaungnya hingga kini.

Klaim di atas tersebut tidak sepenuhnya benar tetapi tidak sepenuhnya juga salah, banyak juga lembaga-lembaga pesantren yang ditengarai mengarahkan peserta didiknya untuk menjadi para "mujahid" dalam pengertian membenarkan tindakan kekerasan untuk kepentingan politiknya atas nama Islam. Bahkan sejumlah Yayasan dari Saudi Arabia, menurut Khaled Abou El Fadl, seorang ahli hukum Islam dari Universitas Yale, menyatakan telah mendanai lembaga-lembaga pendidikan Islam di berbagai Negara mulai dari New York, AS, hingga Nigeria untuk mendorong tindakan-tindakan 'intoleran' dan bersikap ekstrem. Di lembaga-lembaga pendidikan inilah mereka melakukan berbagai pelatihan, mulai dari pencucian otak (brain wash), doktrin 
ideologis hingga latihan militer untuk perang di beberapa Negara seperti Afghanistan, Kashmir, Cechnya, dan sebagainya. ${ }^{1}$

Pasca Orde Baru, pesantren diingatkan kembali pada posisi "Islam dan Negara", era demokrasi menjadi momentum gerakan-gerakan "masa lalu" untuk mengusung lagi ide pembentukan dawlah Islämiyyah. Untuk menyebut beberapa nama pesantren yang sering di sebut sebagai tempat pengkaderan untuk menyiapkan Negara Islam, di antaranya Pesantren Ngruki Solo, Pesantren Hidayatullah di Balikpapan, Kalimantan Timur, Ma'had al-Zaytun di Indramayu. Bahkan khusus Pesantren Ngruki Solo, pengasuhnya Abu Bakar Ba'asyir selalu menyerukan para santrinya untuk melaksanakan syariat Islam melalui cara-cara yang keras (radikal). Sikap radikal Abu Bakar Ba'asyir ini menjadi fenomena baru di dunia pesantren dalam kurun waktu dekade terakhir. ${ }^{2}$

Pada saat yang bersamaan, atmosfir politik dunia pun berubah dengan berakhirnya perang dingin dan Amerika menjadi penguasa tunggal dalam kancah perpolitikan dunia. Perlawanan-perlawanan pun bermunculan, yang di antaranya dari kelompok-kelompok Islam seperti Hizbut Tahrir Indonesia (HTI), Majelis Mujahidin Indonesia (MMI), dan Front Pembela Islam (FPI). Maka dari sinilah gerakan Islam kembali muncul dan berbagai media massa Internasional, nasional, dan lokal pun mengangkat gerakan ini sebagai bentuk gerakan yang mengoyak kemapanan politik Internasional dan nasional. Dalam kaitannya ini, peran pesantren pun dipertanyakan kembali, adakah ia lembaga yang mencetak para santrinya untuk berorientasi politik dengan membenarkan tindakan teroris atas nama Islam atau ranah aman yang menawarkan perdamaian? Keduaduanya barangkali ada tapi untuk kepentingan riset ini, penulis hendak memusatkan pada pesantren sebagai ruang yang aman dan lingkungan yang menawarkan kedamaian.

\section{B. Bina-Damai: Teori Pendekatan dalam Studi Perdamaian}

Bina-damai secara teminologis adalah frase yang jika diterjemahkan dalam bahasa teori pendekatan perdamaian disebut sebagai "peace building". Peace

\footnotetext{
${ }^{1}$ Neng Dara Afifah, "Pesantren dan Budaya Damai," dalam Ahmad Fuad Fanani dan Ahmad Mahromi (ed.), Ijtihad Pesantren tentang Toleransi dan Good Governance, cet. I, (Banten: ICIP, 2009), h. 65. xxviii.

${ }^{2}$ Badrus Sholeh, Budaya Damai dalam Komunitas Pesantren, (Jakarta: Pustaka LP3ES, 2007), h.
} 
(damai) diartikan sebagai kondisi dimana tidak ada lagi peperangan (no war) atau perkelahian (no fighting). Namun secara praksis peace bukan sekedar tidak adanya peperangan, tapi konflik dalam arti luas. Sedangkan building adalah proses atau kepentingan membangun sesuatu, yang dalam bahasa Indonesia baku disebut "bina". ${ }^{3}$

Louis Kriesberg mengembangkan teori bina-damai secara komprehensif. konflik dipandangnya sebagai sesuatu yang natural ada dalam hidup manusia, konflik bisa berakhir secara destruktif atau konstruktif. Menurutnya ada tiga mekanisme dengan apa konflik bisa diselesaikan secara damai dan menjadi sesuatu yang konstruktif, yaitu melalui: (1) mekanisme internal kelompok; (2) mekanisme antar kelompok; dan (3) mekanisme di luarnya (ekstra). Jika diletakkan dalam konteks konflik agama, maka konflik itu bisa diselesaikan melalui mekanisme intra-agama, mekanisme inter-agama, dan mekanisme ekstra-agama. ${ }^{4}$

Dalam mekanisme intra agama, masyarakat dapat mengembangkan kepemimpinan yang pro-perdamaian atau kepemimpinan positif, termasuk pemimpin karismatis. Tersedianya tokoh dan pemimpin agama semacam ini dapat menjadi penyeimbang dan alternatif kepada munculnya kepemimpinan negatif, yaitu mereka yang mendukung kekerasan dan memobilisasi umat dalam rangka kekerasan kolektif. Selaras dengan ini, para pemimpin agama juga dapat dididik di bidang toleransi, sikap saling menghargai, dan hidup berdampingan secara damai.

Selain mekanisme intra agama, ada juga mekanisme internal. Mekanisme internal dapat berfungsi, terutama pada saat terjadinya bencana alam dan konflik sosial yang keras dengan melakukan tindakan sepihak dalam rangka membantu umat agama lain yang sedang dilanda bencana. Tindakan membantu dan menolong ini mungkin terbatas pada pemberian bantuan kemanusiaan dan pertolongan darurat. Akan tetapi, ini menunjukkan kapasitas melakukan amal saleh termasuk kepada pihak lain yang dalam situasi normal dipandang sebagai saingan atau musuh. Mekanisme ini akan meningkatkan rasa saling percaya di antara berbagai komunitas keagamaan yang ada.

\footnotetext{
${ }^{3}$ Longman Advanced American Dictionary, (Essex: Pearson Education Limited, 2007), h. 198.

${ }^{4}$ Louis Krisberg, International Conflict Resolution: From Escalation to Resolution, (Maryland: Rowman \& Littlefield, 1998), h. 98.
} 
Umat Islam seringkali hidup dalam masyarakat yang majemuk, yang warganya menganut agama yang berbeda-beda. Dalam konteks semacam ini, interaksi dan pergaulan sehari-hari yang melibatkan umat Islam dan umat beragama lain adalah salah satu mekanisme penting dalam membina perdamaian. Keluarga yang berasal dari berbagai latar belakang keagamaan dapat saling mengunjungi, bermain, dan bergaul di tempat tinggal mereka. Selain itu, mereka bisa mengikuti berbagai kegiatan masyarakat bersama, misalnya pada saat perayaan keagamaan, upacara adat, saat panen, peringatan hari kemerdekaan, dan kesempatan lain. Begitu juga, anak-anak dari keluarga yang agamanya berbeda bermain di kampung mereka atau di sekolah. Di banyak komunitas di Indonesia, kecenderungan anak dan keluarga bertemu dan bermain ini cenderung menurun, mencerminkan meningkatnya segregasi dan pemilahan sosial berbasis agama. Karenanya, diperlukan usaha sungguhsungguh untuk meningkatkan pergaulan dan interaksi sehari-hari bagi warga yang berasal dari berbagai agama. ${ }^{5}$

\section{Inklusivitas Pesantren}

Pesantren adalah model pendidikan pertama dan tertua di Indonesia. Keberadaan pesantren mengilhami model dan sistem-sistem pendidikan yang ada saat ini. Meski demikian, eksistensi pesantren tidak lapuk digerus zaman dengan segala perubahan yang ada. gambaran lengkap tentang pesantren di Indonesia baru diperoleh melalui sumber-sumber Belanda pada abad ke-19. Berdasarkan statistik resmi pemerintah Kolonial, pada abad ke-19 terdapat sekitar 15.000 pesantren yang tersebar di Jawa dan Madura, dengan jumlah santri sekitar 230.000 orang. Data ini selanjutnya diperkuat catatan perjalanan Snouck Hurgronje, juga di abad ke-19 ke berbagai daerah di Indonesia. Dari catatan perjalanan ini, tergambar dengan jelas bahwa pesantren pada abad ini telah berkembang sedemikian rupa menjadi satu-satunya sarana pendidikan bagi Muslim Indonesia. Daerah yang dikunjungi Hugronje antara lain adalah Garut di Jawa Barat, di mana dia mencatat pesantren Caringin yang dipimpin Haji Muhammad Rafi'i, Pesantren Sukaregang (Kiai Adrangi). Daerah lain di

${ }^{5}$ Rizal Panggabean dan Ihsan Ali Fauzi, "Dari Riset Perang ke Riset Bina-damai, Mengapresiasi Sumbangan Abu Nimer", pengantar dalam Mohammed Abu Nimer, NirKekerasan dan Bina-damai dalam Islam: Teori dan Praktek, (Jakarta: Pustaka Alfabet bekerjasama dengan Yaysan Wakaf Paramadina, 2010), h. xv. 
Jawa Barat adalah Cianjur, Bandung, Bogor, Cirebon dan sejumlah daerah lain yang memang memiliki pesantren. Selain itu, catatan perjalanan ini juga merekam pesantren di berbagai daerah di Jawa Tengah dan Jawa Timur. Sebagaimana halnya di Jawa Barat, pesantren-pesantren yang dikunjungi dipimpin haji atau kiai, bahkan tidak sedikit di antara mereka pernah menuntut ilmu di Mekkah. ${ }^{6}$

Dalam catatan sejarah, pondok pesantren dikenal di Indonesia sejak zaman Walisongo yaitu pada masa Sunan Ampel.7 Ketika itu Sunan Ampel mendirikan sebuah padepokan di Ampel Surabaya dan menjadikannya sebagai pusat pendidikan di Jawa. Para santri yang berasal dari pulau Jawa datang untuk menuntut ilmu agama. Bahkan di antara para santri ada yang berasal Kalimantan dan Sulawesi. Pesantren Ampel merupakan cikal bakal berdirinya pesantren-pesantren di Tanah Air. Sebab para santri setelah menyelesaikan studinya merasa berkewajiban mengamalkan dan menyebarkan ilmunya di daerahnya masing-masing. Maka didirikanlah pondok-pondok pesantren dengan mengikuti apa yang mereka dapatkan di Pesantren Ampel.

Ulama penyebar Islam pertama yang dikenal sebagai Walisongo dalam menanamkan doktrin tauhid Islam terkenal sangat toleran terhadap praktikpraktik keagamaan lokal yang telah mentradisi dalam masyarakat. Toleransi mereka terhadap tradisi lokal terutama mistisisme yang berasal dari HinduBuddha membawa dampak positif dimana Islam menjadi mudah diterima masyarakat. Berkat pendekatan dengan beragam budaya lokal tersebut, bumi Indonesia berkembang menjadi Negara dengan penduduk Muslim terbesar di dunia.

Pesantren pada umumnya tumbuh dan berkembang dari keragaman tradisi dan budaya atau kultur lokal, sehingga sangat kentara dalam ragam budaya tersebut berkembang di tengah-tengah pesantren. Hal itu tampak

\footnotetext{
${ }^{6}$ Alex Susilo Wijoyo, "Shaykh Nawawi of Banten: Texts, Authority, an the Gloss Tradition," Ph.D. Dissertation, (New York: Colombia University, 1997), h. 36-45.

${ }^{7}$ Sunan Ampel adalah anggota dewan Walisongo tertua yang memiliki peranan besar dalam pengembangan Islam di tanah Jawa dan tempat lain di Nusantara. Kedatangan Sunan Ampel ke Majapahit diperkirakan terjadi awal dasawarsa abad ke-15. Sunan Ampel dalam mensyiarkan ajaran Agama Islam mendirikan surau-surau sebagai tempat belajar ilmu Agama yang kemudian sekarang Berkembang menjadi lembaga pesantren. Lihat Agus Sunyoto, Wali Songo: Rekonstruksi Sejarah Yang Disingkirkan, cet. I, (Jakarta: Transpustaka, 2011), h. 109-110.
} 
seperti pola perilaku para santri yang berbeda-beda tradisinya, sikap rendah hati para kiai terhadap pandangan dan budaya yang berbeda, metode pengajaran, materi kitab yang berisi berbagai pandangan ulama, dan sikap akomodatif terhadap tradisi masyarakat. Sehingga tidak mengherankan apabila pesantren disebut sebagai wahana pembelajaran multikulturalisme bagi masyarakat umum. Pengertian multikulturalisme sendiri hampir mirip dengan pluralisme, yaitu sistem nilai atau kebijakan yang menghargai keragaman dalam suatu masyarakat yang didasarkan kepada kesediaan untuk menerima dan menghargai keberadaan kelompok lain yang berbeda suku, etnik, gender, maupun agama. ${ }^{8}$

Di samping itu, di pesantren juga diajarkan perlunya sikap moderat (tawassuț, yang bermakna bahwa komunitas pesantren sangat dianjurkan untuk membangun sikap moderat atau jalan tengah serta menjauhkan ucapan atau perbuatan yang mengarah pada kekerasan atau sikap selalu merasa paling benar dan mau menang sendiri. Dengan demikian, pesantren sudah terbiasa untuk menempatkan kelompok lain yang berbeda etnis, agama, atau kepercayaan lain bukan sebagai ancaman. Namun, sebagai mitra dalam menegakkan moralitas, etika sosial, maupun pengembangan masyarakat untuk mewujudkan kehidupan yang lebih baik pada masyarakat di sekitar pesantren.

Dalam konteksnya yang sekarang, meski relatif baru, pesantren jauh lebih inklusif dalam menghargai pluralisme. Malahan, sejatinya untuk sikap kosmopolit dan egaliter, pesantren adalah sokogurunya. Dua sikap terakhir ini, merupakan nilai-nilai utama yang dipraktikkan di pesantren, baik pesantren yang berjulukan modern (khalaf) maupun pesantren yang berjulukan tradisional (salaf); baik pesantren yang bersifat muqim (menetap) maupun pesantren yang bersifat kalong (tidak menetap); baik pesantren dengan sistem belajar sorogan (individual) maupun pesantren dengan sistem belajar bandongan (kolektif).

Hubungan Islam khususnya pesantren dan agama-agama lain dapat hidup secara damai, dapat juga dilihat dari rumah-rumah ibadah yang didirikan secara saling berhadapan atau berdekatan. Ini misalnya dapat dilihat di Arjawinangun, masjid jami' dan pondok pesantren yang didirikan oleh $\mathrm{KH}$.

\footnotetext{
${ }^{8}$ M. Syafi'i Anwar, "Menggali Kearifan Pesantren untuk Multikulturalisme", dalam Jurnal AlWashatiyyah, No 1, Februari, 2006, h. 62.
} 
Abdullah Sathori, ayah KH. A. Ibnu Ubaidillah, pengasuh pesantren Dar alTauhid sekarang, dibangun sangat berdekatan dengan dua rumah ibadah, yang berupa vihara dan gereja. Bangunan antara vihara dan gereja sendiri berada dalam posisi yang berhadap-hadapan. Hubungan antara Kiai Sathori dengan para pemeluk agama non-Muslim di sana terjalin dengan baik, saling menghargai dan saling membantu. Sampai hari ini hubungan tersebut masih tetap terjalin dengan baik. Tidak ada masalah dalam hubungan mereka. Bahkan sepanjang sejarahnya pergaulan antara umat Islam dan non-Muslim di Arjawinangun membawa pengaruh yang besar dimana banyak warga nonMuslim terutama keturunan Tionghoa menjadi Muslim dan melaksanakan haji.

\section{Pesantren Al-Qodir: Dari Mujahadah Sampai Bakti Sosial}

Pesantren Al-Qodir didirikan oleh Muzaidun bin Abdul Qodir, beliau pernah belajar di salah satu pesantren di Magelang tahun 1960. Saat pulang kembali ke kampungnya, masyarakat menunjuk beliau sebagai guru agama. masyarakat karena merasa yakin dengan ilmu yang dimiliki oleh Muzaidun, sehingga beliau dipercaya untuk menjadi guru mengaji di desa itu. Semakin lama anak-anak yang mengaji semakin bertambah banyak, bahkan ada yang datang dari luar daerah. Dari sinilah beliau mulai merintis, membangun kamarkamar pondokan bagi santri yang datang dari luar daerah dan sejak itu masyarakat mulai menyebut Muzaidun sebagai kiai. Pemberian nama Pondok Pesantren Al-Qodir bermula dari seringnya orang-orang mengatakan bahwa anak-anaknya mengaji di Pondok Pesantren Al-Qodir, ini memberikan inisiatif bagi Kiai Muzaidun untuk memberikan nama pada pesantren dengan nama Pondok Pesantren Al-Qodir.

Pendirian Pesantren Al-Qodir secara fisik dirintis sejak tahun 1980-an. Namun pembangunan gedung-gedungnya yang menjadi asrama para santri, masjid dan fasilitas-fasilitas lain, mulai diupayakan dari tahun 1990 bersamaan dengan mulai datangnya sejumlah santri ke Al-Qodir. Meski sudah menerima santri sejak tahun 1990 dan proses belajar mengajar berjalan, namun secara resmi Pondok Pesantren Al-Qodir berdiri pada tahun 1998 dengan status Yayasan yang dikukuhkan dengan akta notaris dan tercatat resmi di Departemen Agama RI. Pondok Pesantren Al-Qodir memposisikan diri sebagai pondok pesantren salafiyah yaitu pesantren tradisional yang tetap memper- 
tahankan serta mengajarkan kitab-kitab klasik atau kitab kuning sebagai inti pendidikan di pesantren. ${ }^{9}$

Pada masa awal berdiri, fasilitas yang dimiliki masih sangat terbatas. Masjid, asrama, dan fasilitas lain seperti kamar mandi santri dan sebagainya masih kecil dan sedikit. Aktivitas pesantren juga lebih banyak dilakukan di luar kawasan pondok sebab pada masa-masa awal berdiri, pengasuh Pondok Pesantren Al-Qodir lebih sering melakukan pengajian keliling keluar masuk kampung untuk melakukan syiar agama. Ketika sedikit demi sedikit santri mulai datang, aktivitas dakwah keliling tidak lantas berhenti. Bahkan sebaliknya, jika semula hanya menggelar pengajian keliling maka dengan bertambahnya santri, Pondok Pesantren Al-Qodir juga menggelar mujahadah keliling.

Kegiatan mujahadah keliling itu dilaksanakan setiap Sabtu Pon, sehingga sempat dikenal dengan kegiatan Sabtu Ponan. Sebelum acara mujahadah Sabtu Pon digelar, pengasuh dan santri Al-Qodir melakukan bakti sosial bersama masyarakat setempat. Kegiatan itu berlangsung cukup lama. Kegiatan sosial keagamaan yang dibangun sejak lama itu, kemudian menumbuhkan hubungan yang sangat bagus antara Pondok Pesantren Al-Qodir dengan masyarakat dan bertahan sampai sekarang ini. Meski memposisikan diri sebagai pondok pesantren salafiyah yang mengajarkan kitab-kitab klasik atau kitab kuning kepada para santrinya, Pondok Pesantren Al-Qodir juga merasa ikut bertanggung jawab terhadap pembangunan karakter dan moral masyarakat. Tidak heran jika santri yang datang ke Al-Qodir, juga banyak dari kalangan pecandu narkoba yang ingin sembuh. Atau, orang yang mengalami gangguan jiwa untuk mengikuti terapi secara religi.

Sistem pengajaran yang ada di Pondok Pesantren Al-Qodir semula berupa sorogan. ${ }^{10}$ Sistem sorogan ini dilakukan secara terus menerus diulangi sampai bisa, setelah itu baru di tambah pelajaran berikutnya dengan sistem bandongan, yakni sekelompok murid mendengarkan guru yang membaca, menerjemahkan, menerangkan dan sering kali mengulas buku-buku Islam dan

\footnotetext{
${ }^{9}$ Dokumentasi Pesantren Al-Qodir, diambil pada tanggal 20 Desember 2014.

${ }^{10}$ Sorogan adalah sistem pengajian dasar yang diberikan secara individual, dimana seorang guru membaca beberapa baris ayat-ayat al-Qur'an atau kitab-kitab bahasa Arab dan diterjemahkan ke dalan bahasa jawa. Kemudian santri mengikuti dan menerjemahkan kata demi kata seperti yang dilakukan oleh sang guru. Lihat Zamakhsyari Dhofier, Tradisi Pesantren: Studi tentang Pandangan Hidup Kyai, cet. I, (Jakarta: LP3ES, 1982), h. 28.
} 
bahasa Arab, setiap murid memperhatikan bukunya sendiri dan membuat catatan-catatan (baik arti maupun keterangan) tentang kata-kata atau buah pikiran yang sulit.

Dalam operasionalnya kegiatan yang dilakukan ada 2 macam, yakni kegiatan yang bersifat ekstern dan intern, salah seorang pengurus pesantren bercerita tentang kegiatan-kegiatan yang dilaksanakan di pesantren:

“[Pertama] pesantren punya kegiatan ekstern, yaitu meliputi pendidikan keterampilan. Dalam pelaksanaannya pemberian di bidang keterampilan sebagian besar bersifat praktek dan hanya sedikit teori seperti halnya yang sudah disediakan di pondok pesantren, misalnya pertanian (bercocok tanam), perikanan, peternakan, pertukangan dan perdagangan. Lalu ada juga bakti sosial Al-Qodir sebagai wujud kepedulian terhadap masyarakat menengah ke bawah, di antaranya adalah periksa kesehatan gratis, khitanan massal serta pengobatan alternatif yang dilakukan setiap Minggu Pon. Kedua, kegiatan yang intern (keagamaan). Kegiatan ini bertujuan untuk membangun manusia seutuhnya sangat diperlukan adanya kesehatan baik jasmani ataupun rohani yang berhubungan dengan segi mental manusia. Oleh karena itu, kegiatan yang bersifat intern meliputi: pelatihan praktek da'i atau khitabah bagi para santri, Haul Kiai Abdul Qodir yang dilaksanakan setiap bulan Sya'ban, mujāhadah dan psikoterapi yang dilaksanakan setiap malam Jum'at, Pengajian umum sebagai siraman rohani yang diikuti semua masyarakat dengan mengundang pembicara dari luar yang diadakan setiap malam Minggu Kliwon, Pengajian ibu-ibu dan santriwati dipimpin oleh Ibu Nyai Masrur Ahmad MZ yang dilaksanakan setiap malam Selasa. Mujāhadah keliling yang dilaksanakan di rumah-rumah penduduk diadakan setiap malam Minggu Pon".11

Khusus bagi para santri tetap, kegiatan mengaji kitab dilaksanakan pada Setelah Maghrib mengaji dengan model bandongan, Sehabis shalat Isya dan shalat Dzuhur mengaji model sorogan, Khusus bagi para penderita stress, gangguan jiwa dan para korban narkoba, kegiatan amalan dari Kiai Masrur Ahmad MZ diadakan setiap malam Jum'at.

Pada tahun 1965-1966 aktivitas pesantren terganggu dengan munculnya gerakan PKI yang pada saat itu, pesantren dipergunakan tempat berkumpulnya orang-orang yang akan melawan PKI. Dari pesantren ini gerakan dilaksanakan untuk berjuang memusnahkan gerakan PKI yang berusaha memurtadkan masyarakat yang mengenal Islam dan terbebas dari kristenisasi. Kegiatan pe-

11Wawancara dengan Kiai Masrur Ahmad, 19 Desember 2014. 
santren terhenti sama sekali karena kesibukan Kiai Muzaidun dalam membantu perjuangan.

Kegiatan mulai berjalan kembali sekitar tahun 1967 dengan sistem yang ketat yaitu sorogan dan bandongan. Sistem pengajaran baru berubah pada tahun 1987, selain sorogan dan bandongan ditambah sistem madrasah. Perubahan ini tidak lepas dari peran putera kedua Kiai Muzaidun yaitu Kiai Masrur Ahmad yang dipercaya oleh ayahnya untuk membantu mengembangkan pesantren. Pondok Pesantren Al-Qodir melakukan pembinaan kepada para santrinya dengan memberikan berbagai macam pendidikan dan keterampilan sesuai dengan kemampuan dan bakat yang dimiliki setiap santri, tujuannya selain sebagai ikhtiar untuk memenuhi kebutuhan hidup, usaha ini juga digunakan sebagai alat terapi. Bagi mereka yang mengalami gangguan mental, penyakit atau kelelahan jiwa, bekerja merupakan sarana efektif untuk penyembuhan.

Dengan demikian mereka menjadi sehat. Mereka disibukkan untuk bekerja sehingga tidak mempunyai waktu senggang untuk melamun. Kendati demikian, meski dalam menyediakan bentuk usaha santri Kiai Masrur lebih menyukai santri yang mandiri tanpa merepotkan masyarakat, namun tidak berarti Pesantren Al-Qodir memilih sistem sendiri yang terpisah dari aktivitas masyarakat. Bentuk bangunan pondok tanpa pagar pembatas merupakan salah satu bukti keterbukaan dan adanya berbagai kegiatan yang melibatkan masyarakat.

\section{E. Konstruksi Bina-Damai di Pesantren Al-Qodir}

Di tengah carut marutnya hubungan antar agama dan antar umat Islam sendiri bahkan sampai berujung pada tindakan anarkisme di beberapa wilayah di Yogyakarta, ${ }^{12}$ pesantren-pesantren yang ada di Yogyakarta menjadi semakin penting untuk mengambil peran mendamaikan dan menjadi pusat pembelajaran toleransi antar berbagai orang sesama penganut agama. Pesantren sudah seharusnya merekonstruksi dirinya menjadi pusat belajar untuk ukhuwwah Islāmiyyah (persaudaraan sesama ummat Islam), ukhuwwah wațaniyah

\footnotetext{
12Dalam beberapa kasus sepanjang 2013 sampai akhir 2014 terjadi peningkatan radikalisme agama yang berujung pada tindakan kekerasan fisik, sebut saja misalnya penyerangan serta aksi pemukulan yang dilakukan oleh salah satu ormas terhadap para jemaah gereja di Sleman. lalu kemudian di sepanjang tahun 2013 kampanye anti Syi'ah terus disuarakan yang berujung pada wacana pembubaran lembaga Rausyan Fikr.
} 
(persaudaraan sesama bangsa), dan ukhuwwah insāniyyah (persaudaraan sesama manusia).

Pesantren dalam terminologi keagamaan merupakan institusi pendidikan Islam, namun demikian pesantren secara sosiologis merupakan icon sosial yang memiliki pranata tersendiri. Eksistensi pesantren tidak sebatas lembaga pendidikan yang di dalamnya terdapat santri, asrama, masjid dan sistem pendidikan, lebih dari itu pesantren dengan kewibawaan kultural yang dimiliki mempunyai fungsi-fungsi sosial kemasyarakatan yang sangat luas. Pesantren sebagai entitas budaya sudah barang tentu kehadirannya memiliki implikasi terhadap kehidupan sosial yang melingkupinya.

Pesantren Al-Qodir yang didirikan oleh KH. Masrur Ahmad MZ ini, tidak lain adalah untuk ikut menyebarluaskan ajaran Islam sebagai agama yang rahmatan li 'l-álamin. Dalam berbagai macam kegiatan, pengurus pesantren selalu melibatkan, mengajak masyarakat tidak terkecuali dengan umat Kristen di sekitar pondok untuk ikut berpartisipasi. Bentuk bina-damai yang di lakukan warga Pesantren Al-Qodir adalah membangun dialog dengan masyarakat luar pesantren yang berbeda agama (Kristen) dalam bentuk kohesi sosial. Dialog di sini bukan dalam bentuk dialog formal yang pada umumnya di lakukan oleh kalangan elit agamawan dalam interaksi antar agama, melainkan murni dari pola interaksi yang dibangun sendiri tanpa ada tendensi apapun dalam kehidupan sehari-hari. Ruang publik. yang menjadi tempat pertemuan warga pesantren dengan umat Kristen senantiasa dalam semangat kebersamaan, gotong royong dan saling pengertian.

Konstruk bina-damai antar umat Islam-Kristen ini merupakan salah satu strategi gerakan counter-radikalisme Kiai Masrur dengan Pesantren Al-Qodir. Ada beberapa faktor yang membentuk itu. Pertama, figur Kiai Masrur Ahmad sendiri. dan Kedua, Adaptasi Sosial yang teraplikasi dalam pola komunikasi dan interaksi warga pesantren dengan masyarakat sekitar pesantren.

\section{Peran Kiai Masrur Ahmad}

Kiai Masrur lahir dari latar belakang keluarga yang sangat mumpuni dalam bidang ilmu Agama, sejak kecil ia diajari membaca Al-Quran oleh ibundanya Nyai Rabi'ah, sampai mengerti dan menghafal ayat-ayat al-Quran dengan baik, Selanjutnya Masrur belajar dasar-dasar bahasa Arab seperti ilmu Nahwu dan Sharaf kepada ayahandanya. Kedua orang tua beliau dalam mendidik di bidang 
Agama sangat menginginkan anak-anaknya bisa memahami betul agama yang dipeluknya, mengikuti suri tauladan ulama, suka bersilaturrahmi, berpikiran terbuka, layaknya khas kiai-kiai NU yang moderat.

Semenjak lulus dari sekolah menengah pertama Kiai Masrur dititipkan pada seorang ulama di Krapyak yaitu Mbah Munajah. Di sana beliau belajar ilmu-ilmu agama lebih mendalam lagi. Sambil beliau juga sekolah di Madrasah Aliyah Negeri 1 Yogyakarta. Kiai Masrur pernah tercatat sebagai Mahasiswa IAIN Yogyakarta Jurusan Ilmu Perbandingan Agama dan sangat aktif mengikuti kegiatan-kegiatan ekstra kampus, salah satunya beliau bergabung dengan Organisasi Pergerakan Mahasiswa Islam Indonesia (PMII) Cabang Yogyakarta. Selain di pesantren Krapyak, dari Organisasi PMII inilah Kiai Masrur mulai terbiasa dengan perjumpaan-perjumpaan bersama komunitas atau ummat beragama yang lain. ${ }^{13}$

Di lingkungan masyarakat sekitar pesantren Kiai Masrur selalu mendapat tempat terhormat. Didukung suasana kehidupan pedesaan, ototritas Kiai Masrur berlaku tidak hanya di pesantren, tapi juga di lingkungan masyarakat di mana dia tinggal. Ketergantungan masyarakat pada Kiai Masrur demikian besar, yang melampaui batas-batas keagamaan. Melalui pesantren yang dibinanya Kiai Masrur bertindak sebagai perumus realitas. Sikap hidup yang dibangun Kiai Masrur di pesantren secara bertahap kemudian mempengaruhi pola kehidupan sosial-keagamaan masyarakat sekitar. Pengaruh ini juga didukung oleh corak pengajaran Islam di pesantren yang berorientasi praktikal, di mana materi yang diajarkan sebagian besar berhubungan dengan kehidupan keseharian.

Dalam membangun pola bina-damai dengan mekanisme intra-agama, yakni dalam satu komunitas (pesantren), memang membutuhkan pemimpin karismatik yang pro-perdamaian. Pemimpin karismatik itu adalah kiai sebagai pemegang otoritas di dalam pesantren itu sendiri, dan Kiai Masrur menjalankan fungsi itu.

Pesantren pada umumnya dipahami sebagai lembaga pendidikan Islam yang bersifat tradisional yang tumbuh dan berkembang di masyarakat pedesaan, melalui proses sosial yang unik. Pesantren lazimnya dipimpin oleh seorang kiai yang memiliki otoritas keagamaan kuat, untuk mengajarkan ilmuilmu agama kepada para santrinya dengan metode tertentu yang berdasarkan

13Wawancara dengan Kiai Masrur Ahmad, 19 Desember 2014. 
pada kitab-kitab klasik atau kitab kuning. Kiai juga merupakan figur penting dalam menentukan setiap kebijaksanaan kegiatan di pesantren sehingga perkembangan suatu pesantren sangat tergantung oleh kemampuan kepribadian

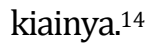

Ketokohan kiai merupakan ciri khas dalam masyarakat pesantren, ini terjadi karena kultur masyarakat Indonesia yang paternalistik, tapi individu kiai sendiri merupakan gelar yang tercipta melalui proses teologis. Gelar kiai atau ulama kepada seseorang bukan karena penyematan seperti pemberian gelar akademik atau gelar kehormatan, namun berdasarkan keistimewaan individunya yang dalam perspektif agama, individu tersebut telah memiliki sifat kenabian (warathat al-anbiyā') seperti: kedalaman ilmu agama, amanah, wira'i, zuhd, tawādu'. Karena keistimewaan tersebut dengan mudah kiai menjadi panutan masyarakat sehingga predikat kiai yang disandang seseorang dijadikan tumpuan segala persoalan oleh umatnya. ${ }^{15}$

Dalam tradisi pesantren telah terbangun konstruk sosial yang menempatkan kiai sebagai pribadi yang memiliki integritas moral dan diikuti oleh masyarakat. konstruksi sosial yang demikian menempatkan kiai pada posisi elit di dalam masyarakat pesantren. Keberadaan elit tidak dapat dihindari dalam kehidupan masyarakat pesantren. ${ }^{16}$ Perspektif Weberian, elit dalam sosiologi diletakkan pada masalah tindakan sosial atau aktor yang memiliki makna subjektif. ${ }^{17}$ Makna subjektif ini berkaitan dengan struktur sosial dalam kehidupan masyarakat, kelompok-kelompok dan masyarakat secara luas sehingga terkait pula dengan fakta objektif yang dikemukakan Durkheim..$^{18}$ Kiai yang berposisi pusat di dunia pesantren menempatkannya sebagai elit tradisional. Kontribusi seorang kiai menjadi penting ketika ia mampu menjalankan perannnya sesuai dengan yang dipegang masyarakat pesantren, sebaliknya bila peran itu dijalankan secara tidak benar, reputasi kiai menjadi pudar.

\footnotetext{
${ }^{14}$ Abdurrahman Wahid, "Pesantren sebagai Subkultur", dalam M. Dawam Rahardjo, (ed.), Pesantren dan Pembaharuan, (Jakarta: LP3ES, 1974), h. 42.

${ }^{15}$ Hamdan Farchan dan Syarifuddin, Titik Tengkar Pesantren; Resolusi Konflik Masyarakat Pesantren, cet. I, (Yogyakarta: Pilar Media, 2005), h. 65.

${ }^{16}$ Achmad Siddiq, Khittah Nahdliyyah, (Surabaya: Balai Buku, 1979), h. 21.

${ }^{17}$ George Ritzer, Sociological Theory, (New York: McGraw Hill, 1992), h. 125.

${ }^{18}$ Antony Giddens, Sociology, (Cambridge: Polity Press, 1993), h. 4.
} 
Jika mengacu kepada pengklasifikasian Hamdan Farchan dan Syafruddin terhadap pesantren yang dibaginya dalam tiga kategori.19 Pesantren Al-Qodir masuk di kategori semi modern. Di pesantren tradisional dan semi modern kiai merupakan faktor sentral yang mempengaruhi kehidupan sosial baik dalam pesantren maupun masyarakat sekelilingnya. Ia bukan hanya sebagai pengendali pesantren tetapi juga berpengaruh luas terhadap lingkungan masyarakat.

\section{Pola Komunikasi dan Interaksi}

Setiap komunitas memiliki bentuk komunikasi dan interaksi yang berbedabeda, disesuaikan dengan kondisi masyarakat yang ada. pola komunikasi dan interaksi yang terbentuk menentukan bagaimana bentuk masyarakat itu. Khususnya dalam membangun keharmonisan dan kerukunan dalam sebuah masyarakat yang majemuk. Pola komunikasi itu terbentuk dalam ruang-ruang sosial dan keagamaan.

Ruang-ruang sosial tersebut sangat menentukan pola komunikasi sebuah komunitas yang majemuk, karena dalam ruang sosial-budaya yang memungkinkan perbedaan tradisi agama khususnya dapat dipertemukan secara unik dan apik. Komunikasi itu sangat mungkin terjadi dalam beragama bentuk dan pola, hal ini ditegaskan oleh Jalaludin Rakhmat bahwa komunikasi selalu terjadi setiap hari dari bangun tidur hingga tidur lagi, setiap orang selalu melakukan komunikasi khususnya dengan orang-orang terdekat dan saling mempengaruhi satu sama lain. ${ }^{20}$ Warga Pesantren Al-Qodir membangun pola komunikasi dan interkasi yang sangat unik di ruang sosial-budaya dengan kehidupan masyarakat yang berbeda keyakinan. Komunikasi dan interaksi antara warga dengan para santri Pesantren Al-Qodir yang berbeda agama, khususnya umat Kristen di daerah Cangkringan Wukirsari terpola dalam beberapa bentuk.

Komunikasi dan interaksi antara masyarakat Kristen dengan warga pesantren dalam kehidupan sosial-keagamaan akan muncul salah satunya saat

\footnotetext{
${ }^{19}$ Saat ini pesantren bisa di klasifikasi dalam menjadi tiga kategori: pertama, pesantren modern. Kedua, pesantren tradisional. Ketiga, pesantren semi modern yaitu perpaduan antara yang tradisional dan modern. Lihat Hamdan Farchan dan Syarifuddin, Titik Tengkar Pesantren; Resolusi Konflik Masyarakat Pesantren, cet. I, (Yogyakarta: Pilar Media, 2005), h. 1-2.

${ }^{20}$ Jalaludin Rakhmat, Psikologi Komunikasi, cet. I, (Bandung: Rosadakarya, 1996), h. 101-102.
} 
ada moment-moment hari-hari besar keagamaan. Misalnya, ketika pelaksanaan shalat Idul Fitri, warga yang beragama Kristen turut serta menjaga keamanan di masjid pondok, setelah selesai shalat warga Kristen biasanya datang ke pesantren dan mengucapkan selamat Idul Fitri ke warga pesantren. Begitu juga kalau ada moment hari besar sperti Maulid Nabi, Isra Mi'raj, warga yang beragama Kristen di undang dan ikut berpartisipasi dalam kegiatan-kegiatan tersebut. Bahkan pada saat pembangunan kamar mandi pesantren ada dari pihak gereja yang ikut memberikan bantuan materiil, dan warga Kristen turut serta membantu bekerja sama-sama dengan santri pesantren.

Begitu pula sebaliknya jika umat beragama Kristen mengadakan ibadah Misa Natal, para santri ikut menjaga keamanan. Tidak hanya itu ada yang menarik dari hubungan antara pesantren dan gereja Katholik ini, Kiai Masrur mengungkapkan Grup rebana Pesantren Al-Qodir sering diundang untuk mengisi acara hiburan di gereja pada saat ibadah Natal.

"Kami sering diundang untuk main rebana, shalawatan, tapi bukan di dalam gereja, di luar gereja. Kita juga ada batasan-batasannya. Biasanya saya dan santri datang ke geraja itu malam tanggal 24 dan paginya tanggal 25, setelah itu kita berkunjung silaturrahmi ke jemaat gereja". ${ }^{21}$

Hal lain yang menjadi penghubung komunikasi dan interaksi antar warga pesantren dengan umat beragama Kristen yaitu dalam bentuk aktivitas sosial seperti gotong royong, pembangunan rumah warga, serta tempat ibadah. Beberapa pekan terakhir ini dunia sosial media dihebohkan dengan adanya foto karangan bunga ucapan selamat mendirikan gereja, yang dikirimkan oleh Pesantren Al-Qodir ke gereja Katholik. Sehingga Kiai Masrur ditelpon oleh tokoh-tokoh Agama yang mengecam tindakan tersebut. Jika melihat latar belakang pendidikan, Aktivitas Kiai Masrur yang sudah dibahas pada bagian sebelumnya, maka ini menjadi hal yang wajar karena beliau memang punya pemikiran yang sangat inklusif.

Pola komunikasi seperti inilah yang menjadikan masyarakat non-Muslim (Kristen) dan warga Pesantren Al-Qodir memiliki ikatan emosional yang kuat dalam membangun hubungan bina-damai. Proses bina-damai tersebut adalah sebagai bentuk kesadaran warga akan pentingnya menjaga keseimbangan

21Wawancara dengan Muhammad Muqarrabin, Ketua Pondok, 19 Desember 2014, jam 10.00. 
hidup yang harmonis dan rukun. Betapa kerasnya hidup dan konflik yang menderai sebuah masyarakat . Disadari hanya dengan kerja bina-damai yang terus menerus konflik dapat diatasi dengan maksimal. Setidaknya konflik manifest dapat dihindari. Bina-damai yang dibangun oleh warga Pesantren AlQodir dengan masyarakat Muslim Kristen di Tanjung Wukirsari Sleman ditopang juga oleh konsepsi berpikir pimpinan pesantren yang senantiasa terbuka, menjaga equilibrium kehidupan baik sesama agama dengan agama yang lain. Kondisi ini tentu mendukung proses bina-damai yang efektif di mana antar komponen masyarakat yang satu dengan yang lain saling mendukung dalam terciptanya kehiduapan yang aman.

\section{F. Kesimpulan}

Berdasarkan uraian di atas, penelitian ini mendapatkan kesimpulan bahwa hubungan bina-damai yang terjalin antara warga pesantren dan masyarakat merupakan salah satu strategi gerakan counter-radikalisme Kiai Masrur Ahmad dengan pesantrennya. Ada beberapa faktor yang membentuk itu. Pertama, figur Kiai Masrur Ahmad sendiri yang sangat berperan penting dalam mengimplementasikan Islam raḥmatan li '-'ālaminn melalui pola pengajaran, materi pembelajaran, yang pada akhirnya membentuk karakter santri yang inklusif, ramah, dan toleran. Kedua, secara praksis warga pesantren mampu melakukan adaptasi sosial dalam bentuk komunikasi-interaktif dengan masyarakat sehingga persepsi radikalisme yang selalu diidentikkan dengan pesantren bisa terbantahkan. Bahkan melalui riset ini peneliti juga menyimpulkan, Pesantren Al-Qodir berhasil melakukan upaya counter-radikalisme yang khas pesantren dan bisa dijadikan contoh bagi komunitas pesantren lainnya dalam meredam radikalisme.

Pesantren Al-Qodir sebagai lembaga pendidikan adalah tempat bersemayam kehidupan yang penuh toleran dan perdamaian. Di dalamnya para santri bukan hanya dikenalkan dengan ilmu-ilmu keislaman dan ilmu lainnya, tetapi juga diajarkan tentang ketekunan, kesederhanaan, kemandirian, solidaritas, antar sesama, baik itu sesama umat beragama Islam maupun umat agama yang lain. Hidup di pesantren berarti adalah hidup siap menerima yang lain yang berbeda karena pesantren terdiri dari berbagai macam suku dan golongan. Sebab itu merupakan sebuah ironi bila ada dari masyarakat pe- 
santren yang melakukan kekerasan entah atas nama apapun. Kekerasan bukanlah yang dianjurkan oleh Islam, sebab itu pesantren sebagai lembaga yang mengejawentahkan nilai-nilai Islam juga sejatinya menolak berbagai bentuk kekerasan dan sikap intoleransi.[w] 


\section{BIBLIOGRAFI}

Anwar, M. Syafii, “Menggali Kearifan Pesantren untuk Multikulturalisme”, Jurnal Al-Washatiyyah, No. 1, 2006.

Dhofier, Zamakhsyari, Tradisi Pesantren: Studi tentang Pandangan Hidup Kyai, Jakarta: LP3ES, 1982.

Giddens, Antony, Sociology, Cambridge: Polity Press, 1993.

Hamdan, Farchan dan Syarifuddin, Titik Tengkar Pesantren: Resolusi Konflik Masyarakat Pesantren, Yogyakarta: Pilar Media, 2005.

Hasbi, Indra, Pesantren dan Transformasi Sosial: Studi Atas Pemikiran KH. Abdullah Syafi ie dalam Bidang Pendidikan Islam, Jakarta: Penamadani, 2003.

Longman Advanced American Dictionary, Essex: Pearson Education Limited, 2007.

Krisberg, Louis, International Conflict Resolution: From Escalation to Resolution, Maryland: Rowman \& Littlefield, 1998.

Muhammad, Husein, "Pesantren sebagai Sumber Pelajaran Pluralisme dan Multikulturalisme", dalam Ahmad Fuad Fanani dan Ahmad Mahromi. (ed.), Ijtihad Pesantren tentang Toleransi dan Good Governance, Banten: ICIP, 2009.

Rizal Panggabean dan Ihsan Ali-Fauzi, "Dari Riset Perang ke Riset Bina-damai, Mengapresiasi Sumbangan Abu Nimer", pengantar dalam Mohammed Abu Nimer, NirKekerasan dan Bina-Damai dalam Islam: Teori dan Praktek, Jakarta: Pustaka Alfabet bekerjasama dengan Yaysan Wakaf Paramadina, 2010.

Rakhmat, Jalaludin, Psikologi Komunikasi, Bandung: Rosadakarya, 1996.

Ritzer, George, Sociological Theory, New York: McGraw Hill, 1992.

Siddiq, Achmad, Khittah Nahdliyyah, Surabaya: Balai Buku, 1979.

Sunyoto, Agus, Wali Songo: Rekonstruksi Sejarah yang Disingkirkan, Jakarta: Transpustaka, 2011.

Wahid, Abdurrahman, "Pesantren sebagai Subkultur", dalam M. Dawam Rahardjo, (ed.), Pesantren dan Pembaharuan, Jakarta: LP3ES, 1974.

Wijoyo, Alex Susilo, "Shaykh Nawawi of Banten: Texts, Authority, an the Gloss Tradition", Disertasi,, New York: Colombia University, 1997. 


\section{Wawancara:}

Kiai Masrur Ahmad, Pengasuh Pondok Pesantren Al-Qodir,19 Desember 2014.

Muhammad Muqarrabin, Ketua Pondok Pesantren Al-Qodir, 19 Desember 2014, jam 10.00 . 